\title{
ARE FOREIGN BANK SUBSIDIARIES MORE PROFIT EFFICIENT THAN DOMESTIC ONES? - AN ANALYSIS ON EARNING APPROACH OF PRIVATE SECTOR BANKS, BANGLADESH
}

\author{
Jace Saha ${ }^{1}$

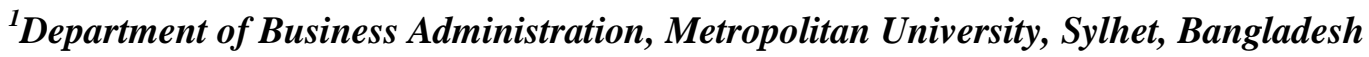 \\ Nishath Anjum ${ }^{2}$ \\ ${ }^{2}$ Department of Business Administration, Metropolitan University, Sylhet, Bangladesh
}

Article DOI: $\underline{\text { https://doi.org/10.36713/epra3904 }}$

\begin{abstract}
Profitability indicates the efficiency with which the operations of the business are carried on. The measurement of profitability in banking is necessary to improve the financial soundness of banks. The banking in private sector of Bangladesh comprises both domestic and foreign bank subsidiaries. The main purpose of this study is to determine and compare the profitability of foreign banks with domestic conventional and Islamic banks operating in Bangladesh. Among various variables here two most important profitability ratios: Return on Asset and Return on Equity are used to analyze the performance of private sector banks. A sample of nine private sector banks has been selected randomly to measure and compare their performance for the period of 2010 to 2018 . Each year the average ratios were considered. In this work, t-test analysis is used to determine the significance of this study. The study has shown that there is no significant difference between the profit efficiency of foreign bank subsidiaries and domestic banks (Islamic and Conventional).
\end{abstract}

KEYWORDS: Profitability, Islamic Banks, Conventional Banks, Foreign Banks, Private Sector.

\section{INTRODUCTION}

As a financial intermediary, a bank accepts deposits and channels those deposits into lending activities either directly by loaning or indirectly through capital markets. The banking sector in Bangladesh consists of different types of institutions. The central bank of the country is Bangladesh bank and is the chief regulatory authority in the banking sector. At present there are 62 scheduled banks, 5 non-scheduled banks and 35 Financial Institutions operating in Bangladesh whose activities are regulated and supervised by Bangladesh bank. The Scheduled Commercial Banks include state owned banks (SOBs), private commercial banks (PCBs) and foreign commercial banks (FCBs). Among the state owned banks (SOBs), there are 6 state owned commercial banks (SOCBs) and 3 Specialized banks (SDBs) operating in the country which are fully or majorly owned by the Government of Bangladesh. There is a total of 43 domestic private commercial banks are in operation right now majorly owned by private entities and classified into two types; Conventional banks and Islamic banks. Conventional PCBs perform the banking functions in conventional fashion i.e. interest based operations and Islamic PCBs execute banking activities according to Islamic Shariah-based principles i.e. Profit-Loss Sharing (PLS). There are 36 conventional PCBs and 8 Islamic Shariah-based PCBs are now operating in the Bangladesh. Moreover, at present in total of 9 foreign 


\section{SJIF Impact Factor: 6.260| ISI I.F.Value:1.241| Journal DOI: 10.36713/epra2016 ISSN: 2455-7838(Online)}

EPRA International Journal of Research and Development (IJRD)

Volume: 5 | Issue: 1 | January 2020

- Peer Reviewed Journal

commercial banks (FCBs) are operating in Bangladesh as the branches of the banks which are incorporated in abroad. (Statistics dept, BD bank 2019).

Many of these foreign banks were operating since independence and were permitted to continue doing business in Bangladesh after the independence. Moreover, in recent, the market structure of the banking industry has undergone significant changes as ongoing financial liberalization encourages the entry of foreign bank into domestic banking market which results in a substantial impact on banking competition. They tend to increase the efficiency of the local banking system, bring in more sophisticated financial services and have the ability to nurse weak banks back to health. One may expect that foreignowned banks should be more profitable than domestic-owned ones because of higher investment but the opposite can be true. The study examines the profitability position of foreign banking comparison with domestic bank in the same market (Bangladesh market). It only focuses on the private sector banks of Bangladesh, state owned banks are not included in the study. The study examines profit efficiency by utilizing the banks performance data for the period of 9 years (2010-2018) for foreign banks and domestic banks (both Conventional and Islamic banks on private sector defines the sample for domestic banks in the market) operating in Bangladesh. The results of this research work will answer the question that whether Foreign banking sector's performance outperform domestic conventional and Islamic banking sector or not.

\section{LITERATURE REVIEW}

The performance of bank as a financial institution in both developing and developed country is essential for financial sectors steadfastness and economic magnification. There have variety of banking pattern and systems. Among them domestic banking, Islamic banking and foreign banking system have a great involvement to its customers and the economy as well (Noman, 2015). Both domestic and foreign bank subsidiaries are operating in the private sector of Bangladesh. Foreign banks are those banks of which more than $50 \%$ of the shares are owned by nondomestic residents. This states that a bank may be a domestic bank in one country, but a foreign bank across the world else. For example, Citibank is a domestic bank in the US but it will be regarded as a foreign bank in all other countries (Lensink et al., 2008). Domestic banks are operating in two ways; Islamic and
Conventional. In general, Islamic banking system is based on Shariah principle, while conventional banking system is based on interest rate. Shariah is a set of norms, values and laws that go to make up the Islamic way of life. Characteristics of Shariah -compliant banking and financial system are free from riba. Riba is prohibited in Islamic banking system, because Islamic banking system is based on the sharing of risk and profit. Interest is considered to be the price of credit, reflecting the opportunity cost of money in Conventional banking system (Abduallah A.M., Yasser Q.R.,Entebang H., 2014). The bank is evaluated based on profit and loss as the same way for other business. (Khan, 2009). Banks with higher total deposits, credits, assets and shareholders' equity do not always show better profitability performance (Almazari, 2011). Differences in banking market structure across country play a significant role on banks profitability. Profit is an important factor for the endurance of a bank and one of the essential indicators of its performance. (Short \& Bourke 1979, 1989).

The profit efficiency of banks has been measured using a mixture of financial ratio analysis (Dutta, et al., 2011). Banks must improve ROA, ROE and other monitoring, assessment and performance evaluation metrics, in order to build up the economic conditions of a country (Ahmed, et al., 2006). ROA basically sheds light and specifies the ways that management exploits its assets to generate earnings. Return on Asset (ROA) is also an indicator of operational efficiency, in simple words, ROA conveys information on the amount of income generated from each unit of an asset on an average. Return on Equity (ROE), on the other hand, is a dimension that contributes in understanding the working of the management of the organization with respect to the earnings or income generated from the owner's equity (Uddin, et al. 2017). ROE can be defined to assess the returns on the equity holders in order to evaluate the growth of their investments (Petersen and Schoeman, 2008).

Previous studies have examined the differences in profitability determinants of domestic and foreign banks. Tahir et al. (2010) conducted a study on Malaysian banks based on the data from 2006 to 2006, found that profit ratios are slightly higher for foreign banks relative to domestic banks but in case of other variables domestic banks were more efficient than foreign ones. Another study conducted by Elyor (2009) based on the data for a period of 2003 to 2008 on Malaysian banks, establishes a result that foreign banks have strong capital but the domestic banks are more profitable. The study of Azam and Siddiqui (2012) analyze and compare the profitability of domestic and 


\section{EPRA International Journal of Research and Development (IJRD) \\ Volume: 5 | Issue: 1 | January 2020 \\ - Peer Reviewed Journal}

foreign banks based on a quarterly data sample of 36 commercial banks in Pakistan during the period 2004 and 2010. They found that foreign banks are more profit efficient than both types of domestic banks (Conventional \& Islamic) together. Their results also show that domestic and foreign banks have different profitability determinants. In other words, factors which are important in determining the profitability of domestic banks are not necessarily significant for the foreign. Another study conducted by Azam and Siddiqui (2004) on Pakistani banks, found that locally prohibited commercial banks in Pakistan are more profitable than the foreign controlled. With regard to the volume of the profit reflecting on the earnings per share, however, Pakistan's locally controlled banks are more capital proficient. Net interest margin shows a positive significant relationship with ROE for the foreign sector. The capitalization level has a negative effective with ROE along with the finding of no

$$
\begin{aligned}
& \text { Return on Asset }(\mathrm{ROA})=\frac{\text { Net Income after Tax }}{\text { Total Asset }} \\
& \text { Return on Equity }(\mathrm{ROE})=\frac{\text { Net Income after Tax }}{\text { Total Equity }}
\end{aligned}
$$

ROA shows how a bank can convert its asset into net earnings. The higher value of this ratio indicates the higher financial capability of a firm. ROE indicates how a bank can generate profit with the money shareholders have invested. The higher value of this ratio shows higher financial performance. The population for this study are domestic Islamic and significance with the GDP Growth. The high return on average assets (ROAA) was found to be associated with well-capitalized banks and lower cost to income ratios (Kosmidou, 2008).

\section{METHODOLOGY}

This study is investigative in nature and the data has been collected from secondary sources i.e., the financial statements of the selected banks' websites. Then the ratio analysis is used to scrutinize the collected information. This study investigates the profit efficiency of foreign banks with domestic conventional and Islamic banks by using profitability ratios. The two most important profitability ratios are used to compare the financial performance of selected banks i.e., Return on Asset and Return on Equity.

\begin{tabular}{|c|c|c|}
\hline Islamic Banks & Domestic Conventional Banks & Foreign Conventional Banks \\
\hline Islami bank Ltd. & AB Bank Ltd. & HSBC Ltd. \\
\hline Shahajalal Islami Bank Ltd. & Prime Bank Ltd. & Standard Chartered Bank Ltd \\
\hline Al-Arafa Islami Bank Ltd. & National Bank Ltd. & Habib Bank Ltd. \\
\hline
\end{tabular}

The financial data of all foreign banks, Islamic banks and domestic Conventional banks were extracted from the respective websites for the period 2010-2018. For better comparison, each year the average ratios of ROA and ROE were used. The findings of this study are presented in both tabulate and graphical forms. The $\mathrm{t}$-test is applied here to analyze the data and SPSS- 22 is used to perform the t-test.

\section{RESEARCH HYPOTHESIS}

The following hypothesis are used to test the differentiations of profitability ratio of domestic conventional banks, foreign conventional banks and Islamic banks:
Conventional banks that operate inside Bangladesh and foreign conventional banks incorporated outside of Bangladesh but operating here. The sample size is comprised of three full-fledged domestic Islamic banks, three domestic Conventional banks and three foreign conventional banks which were selected in a random basis. The selected banks are: 
SJIF Impact Factor: 6.260| ISI I.F.Value:1.241| Journal DOI: 10.36713/epra2016 ISSN: 2455-7838(Online)

EPRA International Journal of Research and Development (IJRD)

Volume: 5 | Issue: 1 | January 2020

- Peer Reviewed Journal

\begin{tabular}{|c|c|c|c|c|c|c|}
\hline Year & \multicolumn{2}{|c|}{ Foreign Conventional Banks } & \multicolumn{2}{c|}{ Domestic Conventional Banks } & \multicolumn{2}{c|}{ Islamic Banks } \\
\hline & ROA & ROE & ROA & ROE & ROA & ROE \\
\hline $\mathbf{2 0 1 0}$ & 0.0059106397 & 0.106507113 & 0.0347517091 & 0.283330223 & 0.0211447524 & 0.243086074 \\
\hline $\mathbf{2 0 1 1}$ & 0.0055833979 & 0.107158299 & 0.0117781658 & 0.115523788 & 0.0271140054 & 0.13687041 \\
\hline $\mathbf{2 0 1 2}$ & 0.0041399968 & 0.105027192 & 0.0094580118 & 0.096163002 & 0.0298002128 & 0.15280657 \\
\hline $\mathbf{2 0 1 3}$ & 0.0084468436 & 0.14414774 & 0.0077548059 & 0.082417833 & 0.0107754092 & 0.125170809 \\
\hline $\mathbf{2 0 1 4}$ & 0.0082952734 & 0.117177952 & 0.0084114729 & 0.090441524 & 0.0076380409 & 0.092356633 \\
\hline $\mathbf{2 0 1 5}$ & 0.0162594636 & 0.194438351 & 0.0091269291 & 0.086624348 & 0.0082738928 & 0.102471147 \\
\hline $\mathbf{2 0 1 6}$ & 0.0056958149 & 0.128744392 & 0.0105160610 & 0.10127059 & 0.0092170231 & 0.125677282 \\
\hline $\mathbf{2 0 1 7}$ & 0.0033010910 & 0.036297589 & 0.0189328655 & 0.056547945 & 0.0069156682 & 0.110614029 \\
\hline $\mathbf{2 0 1 8}$ & 0.0038650517 & 0.053937579 & 0.0132372803 & 0.062656538 & 0.0064499195 & 0.107204814 \\
\hline
\end{tabular}

Table 1: Average value of ROA and ROE of foreign conventional banks, domestic conventional banks and Islamic banks
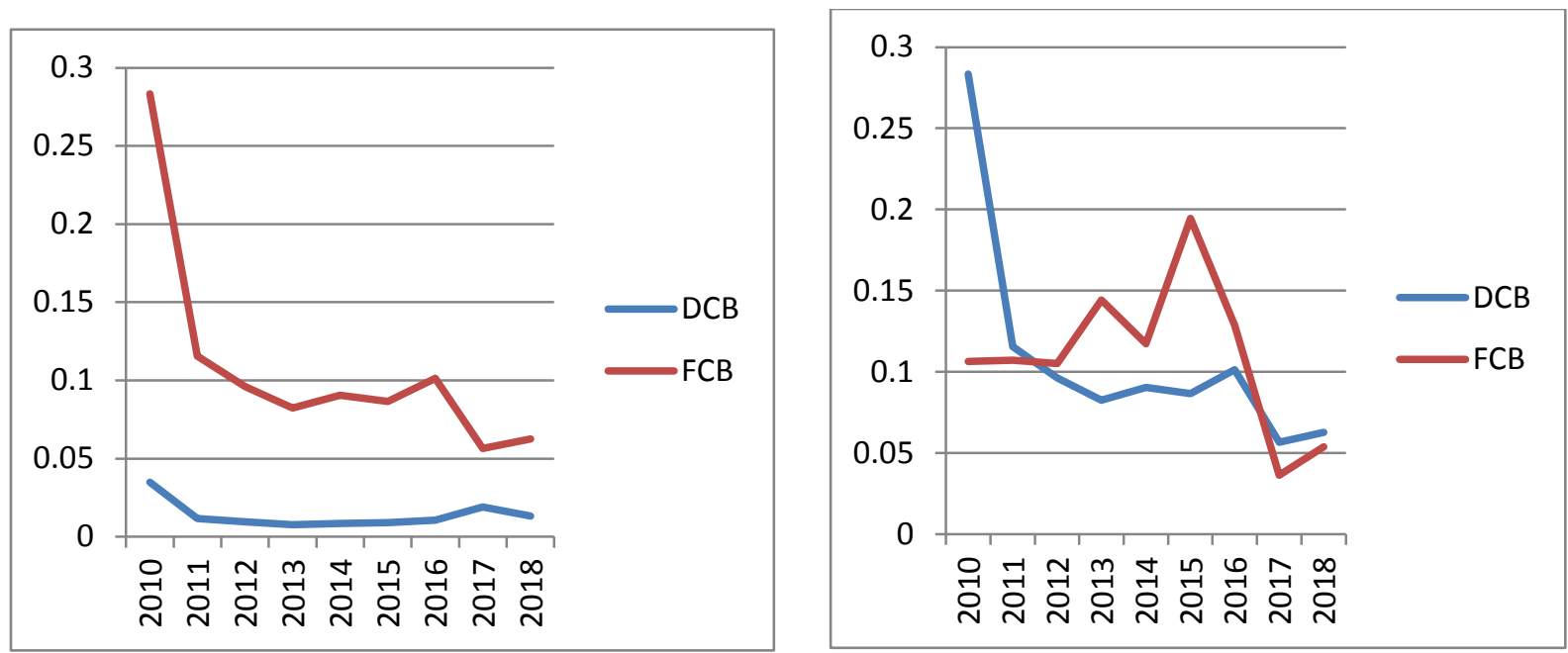

Figure1: ROA of foreign \& domestic conventional Banks Figure 2: ROE of Foreign \& domestic conventional Banks (Source: Authors' Calculations 2019)

From the graph, it is seen that foreign banks are performing well than conventional banks based on both return on asset- ROA (Figure 1) and on return on equity- ROE (figure 2). 
EPRA International Journal of Research and Development (IJRD)

Volume: 5 | Issue: 1 | January 2020

- Peer Reviewed Journal

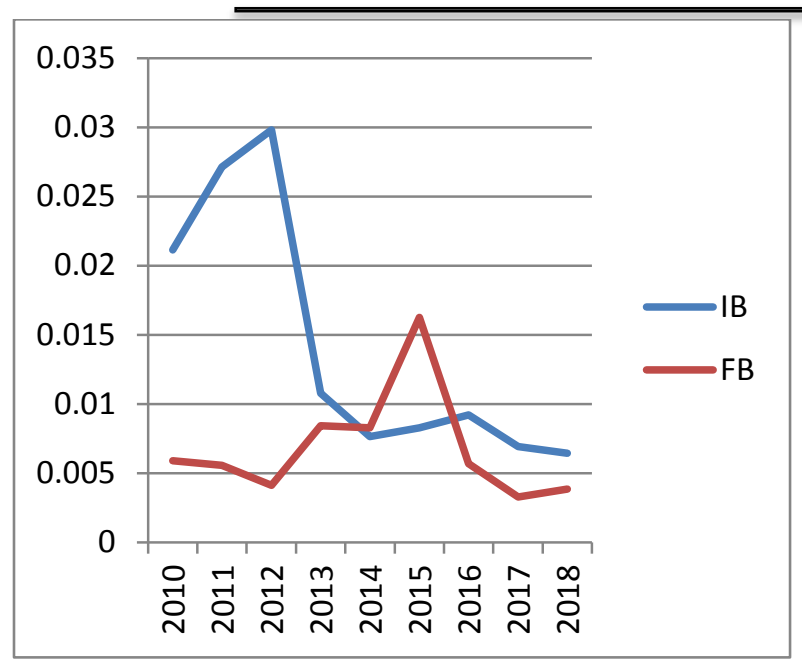

Figure 3: ROA of Foreign \& Islamic Banks

(Source: Authors' Calculations 2019)

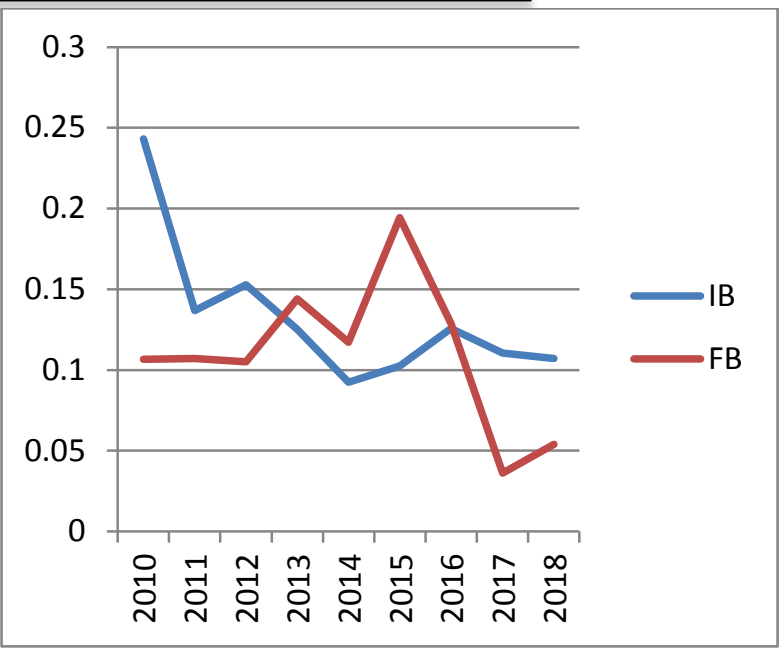

Figure 4: ROE of Foreign \& Islamic Banks

From the graph (figure 3), it is seen that Islamic banks are performing well than foreign banks based on return on asset (ROA) and foreign banks are performing well than Islamic banks (figure 4) based on return on equity (ROE).

Test of hypothesis 1: There is a statistically significant difference in the profitability ratio between foreign conventional banks and Domestic conventional banks.

Paired Samples T-Test: Two-Sample Assuming Unequal Variances

\begin{tabular}{|c|c|c|c|c|c|c|c|c|c|}
\hline & & \multicolumn{5}{|c|}{ Paired Differences } & \multirow[b]{3}{*}{$\mathbf{t}$} & \multirow[b]{3}{*}{ df } & \multirow[b]{3}{*}{$\begin{array}{l}\text { Sig. (2- } \\
\text { tailed) }\end{array}$} \\
\hline & & & & & \multicolumn{2}{|c|}{\begin{tabular}{|c|}
$95 \%$ Confidence \\
Interval of the \\
Difference
\end{tabular}} & & & \\
\hline & & Mean & $\begin{array}{c}\text { Std. } \\
\text { Deviation }\end{array}$ & $\begin{array}{l}\text { Std. Error } \\
\text { Mean }\end{array}$ & Lower & Upper & & & \\
\hline Pair 1 & $\begin{array}{l}\text { ROA of Foreign } \\
\text { conventional banks \& } \\
\text { Domestic conventional } \\
\text { banks }\end{array}$ & .00694 & .01044 & .00348 & -.00108 & .01496 & 1.995 & 8 & .081 \\
\hline Pair 2 & $\begin{array}{l}\text { ROE of Foreign } \\
\text { conventional banks \& } \\
\text { Domestic conventional } \\
\text { banks }\end{array}$ & -.00205 & .07808 & .02603 & -.06207 & .05796 & -.079 & 8 & .939 \\
\hline
\end{tabular}

Table 2: T-Test (Difference between ROA \& ROE of Foreign \& domestic conventional banks)

The t-test statistics (Table 2$)$ of pair 1, (1.99, df8 ) and pair $2(-.07, \mathrm{df}-8)$ indicates the p-value of .081 and .939 which are more than the significant level of $5 \%$. This result fails to reject the null hypothesis and consequently rejects alternative hypothesis. Therefore, the ROA and ROE of foreign conventional banks and domestic conventional banks are not differs significantly regarding profitability. So, we can say that, there is no statistically significant difference in the profitability ratio between foreign conventional banks and domestic conventional banks. 


\section{EPRA International Journal of Research and Development (IJRD)}

Volume: 5 | Issue: 1 | January 2020

- Peer Reviewed Journal

Test of hypothesis 2: There is a statistically foreign conventional banks and Islamic banks. significant difference in the profitability ratio between

Paired Samples T-Test: Two-Sample Assuming Unequal Variances

\begin{tabular}{|c|c|c|c|c|c|c|c|c|c|}
\hline & & \multicolumn{5}{|c|}{ Paired Differences } & \multirow[b]{3}{*}{$\mathbf{t}$} & \multirow[b]{3}{*}{ df } & \multirow[b]{3}{*}{$\begin{array}{l}\text { Sig. (2- } \\
\text { tailed) }\end{array}$} \\
\hline & & & & & $\begin{array}{r}95 \% \text { Con } \\
\text { Interva } \\
\text { Differ } \\
\end{array}$ & $\begin{array}{l}\text { fidence } \\
\text { of the } \\
\text { ence }\end{array}$ & & & \\
\hline & & Mean & $\begin{array}{c}\text { Std. } \\
\text { Deviation }\end{array}$ & $\begin{array}{c}\text { Std. Error } \\
\text { Mean }\end{array}$ & Lower & Upper & & & \\
\hline Pair 1 & $\begin{array}{l}\text { ROA of Foreign } \\
\text { conventional banks \& } \\
\text { Islamic banks }\end{array}$ & .00731 & .01104 & .00368 & -.00117 & .01580 & 1.988 & 8 & .082 \\
\hline Pair 2 & $\begin{array}{l}\text { ROE of Foreign } \\
\text { conventional banks \& } \\
\text { Islamic banks }\end{array}$ & .02254 & .06619 & .02206 & -.02835 & .07342 & 1.021 & 8 & .337 \\
\hline
\end{tabular}

Table 3: T-Test (difference between ROA \& ROE of Foreign and Islamic banks)

The t-test statistics (Table 3$)$ of pair $1,(1.98$, df$8)$ and pair $2(1.02, \mathrm{df}-8)$ indicates the p-value of .082 and .337 which are more than the significant level of $5 \%$. This result fails to reject the null hypothesis and consequently rejects alternative hypothesis. Therefore, the ROA and ROE of foreign and Islamic banks are not differs significantly regarding profitability. So, we can say that, there is no statistically significant difference in the profitability ratio between foreign conventional banks and Islamic banks.

\section{LIMITATIONS \& SCOPE FOR FURTHER STUDIES}

This research paper has some limitations. First, random but convenient sampling was used to select banks in this study. In future studies, any researcher may increase the number of banks to overcome the limitation. Secondly, this study only used ROA \& ROE to measure profit efficiency of banks which may limit the propriety of result. In further studies, the researcher may use other profitability ratios along with ROA \& ROE to improve the accuracy of result. Despite these limitations, the study has provided important findings and contributed significantly to the body of research knowledge regarding profit efficiency of banks in Bangladesh.

\section{CONCLUSIONS}

Among all other financial institutions, the banking industry execute most vital role in the economic development of a country especially in the developing economy like Bangladesh. Among the private sector banks of Bangladesh, both Islamic and Conventional banks are still very successful and competitive in their banking operations. Foreign bank participation has been a fact of the larger process of financial liberalization and international coalition experienced by Bangladesh in recent years. Empirical evidence shows that in emerging markets, foreign banks are more profitable and more efficient than domestic banks. As domestic banks have private information about their incumbent clients but foreign banks have better screening skills. (Claeys, Hainz 2006,). As a result, foreign bank entry would drive down a country's average interest rate for new loans. Otherwise, some studies have noted that foreign banks might not have knowledge of the specific market at the time of entrance or that they might be otherwise disadvantaged compared with domestic bank (Berger et al., 2000; Kosmidou et al., 2004). Although there is a common observation among the people of Bangladesh that foreign banks are performing well than domestic ones, it is not true in practical point of view. As the domestic banking sector of Bangladesh comprise both conventional and Islamic banking, it is imperative to compare both types of banks performance with the performance of foreign bank subsidiaries to measure 


\section{SJIF Impact Factor: 6.260| ISI I.F.Value:1.241| Journal DOI: 10.36713/epra2016 ISSN: 2455-7838(Online) EPRA International Journal of Research and Development (IJRD) Volume: 5 | Issue: 1 | January 2020 - Peer Reviewed Journal}

their profit efficiency. However previous literature shows less attention on this case. This study used performance data for 9 years (2010 to 2018) for all three kinds of banks operating in private sector of Bangladesh and thus compared the performance of Foreign bank subsidiaries separately with both domestic Conventional and Islamic banks in terms of profitability ratios, i.e. Return on asset (ROA) and Return on equity (ROE). This research has shown that the ROA \& ROE of foreign and domestic banks fluctuates year to year. In one year, the foreign banks may perform well but in another year the domestic banks perform better than foreign banks. By analyzing the data from last nine years, this study concluded that the Return on asset (ROA) and Return on equity (ROE) of foreign and domestic banks not differs significantly. The results indicates, more specifically, there is no significant difference between the profit efficiency of foreign bank subsidiaries and domestic banks in private sector of Bangladesh.

\section{REFERENCES}

1. Noman, M. H. A., (2015), An Empirical Investigation of Profitability of Islamic Banks in Bangladesh. Global Journal of Management and Business Research: C Finance, Volume No. 15, p. 113.

2. Dutta, P. Ghosh, B., and Tuhin, M., (2011), Financial Performance in Banking Sector in Bangladesh: A Comparative Study of Some Selected Private Commercial Banks, Journal of Banking and Financial Services. Volume 5, p. 129-138.

3. Khan, A. R., (2009), Bank Management: A fund Emphasis, Dhaka: Decent Book House, 2nd edition, p. 51-68.

4. Ahmed, E., Rahman, Z., and Ahmed, R. I., (2006), Comparative analysis of loan recovery among Nationalized, Private and Islamic banks of Bangladesh, BRAC University Journal, 3(1), p. 3552.

5. Short, B. (1979), The Relation between Commercial Bank Profit Rates and Banking Concentration in Canada. Western Europe and Japan, Journal of Banking and Finance, 3(3), 209-219.

6. Bourke, P. (1989), Concentration and other Determinants of Bank Profitability in Europe North America and Australia. Journal of Banking and Finance, 13(1), 66-79.

7. Uddin, M. S., Ahsan, M. K., and Haque, M. A., (2017), Comparisons of Financial Performance of Islamic Banks and Conventional Banks in Bangladesh, ABC Research Alert, Vol 5. p. 1-12.

8. Petersen, M. and Schoeman, I., (2008), Modeling of Banking Profit via Return-on-Assets and Return-onEquity. Proceedings of the World Congress on Engineering, p. 1-6
9. Hassan, M. K., 1999, Islamic Banking in Theory and Practice: The Experience of Bangladesh, Managerial Finance, 25(5), p. 60-113.

10. Kosmidou, K., (2008), The Determinants of Banks' Profits in Greece during the Period of EU Financial Integration, Managerial Finance, 34(3), p. 146-159.

11. Tahir, I., AbuBakar, N., Haron, S. (2010), Cost and Profit Efficiency of the Malaysian Commercial Banks: A Comparison between Domestic and Foreign Banks. International Journal of Economics and Finance, 2, 186-197.

12. Elyor, S. (2009), Factors Affecting the Performance of Foreign Banks In Malaysia. Master of Science (Banking), College of Business, University Utara Malaysia.

13. Azam, M., Siddiqui, S. (2012), Domestic and Foreign Banks' Profitability: Differences and Their Determinants. International Journal of Economics and Financial Issues, (2)1, 33-40.

14. R. Lensink, A. Meesters, I. Naaborg, (2008), Bank efficiency and foreign ownership: Do good institutions matter? Journal of Banking and Finance, pp. 834-844.

15. Azam M. \& Siddiqui S. (2004), Domestic and Foreign Banks' Profitability: Differences and Their Determinants. International Journal of Economics and Financial Issues 2: p. 34-41.

16. Abduallah A.M., Yasser Q.R., Entebang H., (2014), Comparison between Islamic and Conventional Banking: Evidence from Malaysia, International Journal of Islamic Banking \& Finance, Vol. 4, Issue 1.'

17. Berger, A.N., DeYoung, G., Gregory, F., Udell, 2000. Globalisation of financial institutions: Evidence from cross-border banking performance. Brookings-Wharton Papers on Financial Service 3, 23-120.

18. Claeys, S., Hainz, C., 2006. Acquisition versus Greenfield: The impact of the mode of foreign bank entry on information and bank lending rates. Governance and the Efficiency of Economic Systems Discussion Paper No. 95.

19. Kosmidou, K., Pasiouras, F., Doumpos, M., Zopounidis, C., 2004. Foreign versus domestic banks' performance in the UK: a multicriteria approach. Computational Management Science 1 (3-4), 329-343. 